\title{
Effect of greenhouse heights on the production of aromatic herbs in Colombia. Part 1: Chives (Allium schoenoprasum L.)
}

\section{Efecto de la altura del invernadero en la producción de hierbas aromáticas en Colombia. Parte 1: Cebollín (Allium schoenoprasum L.)}
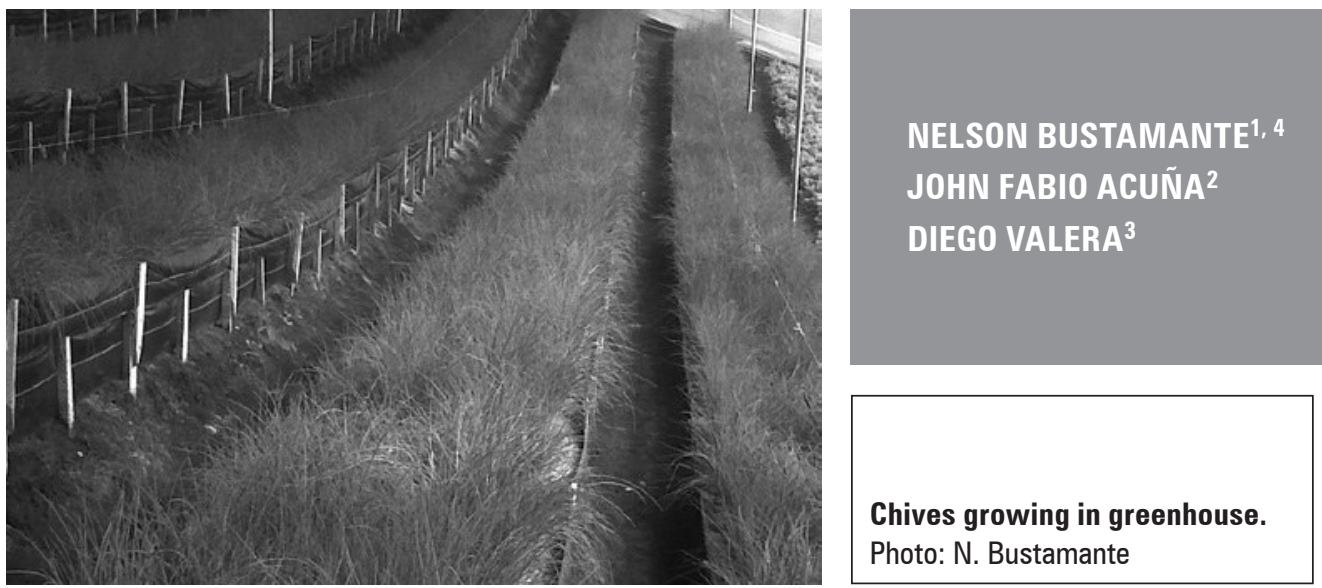

\begin{abstract}
This study aimed to evaluate the effect of greenhouse heights on a crop of chives. Tests were conducted in three greenhouses that had the same dimensions, but with different channel heights of 2; 2.5 and $3 \mathrm{~m}$, located in Carmen de Viboral, Antioquia $\left(6^{\circ} 05^{\prime} 09^{\prime \prime} \mathrm{N}\right.$ and $75^{\circ} 20^{\prime} 19^{\prime \prime} \mathrm{W}, 2.150 \mathrm{~m}$ a.s.l.). Temperature and relative humidity measurements were taken every 30 min for 3 years, and the crop production was assessed. A multiple linear regression, colinearity analysis, and analysis of heteroscedasticity were carried out to determine the climatic variations caused by the differences in height of the greenhouses and to determine differences in the production levels. For the statistical analysis, SPSS was used. The results indicated that, under the studied conditions, the greenhouse height directly affected the internal weather condition; specifically, a 1 $\mathrm{m}$ reduction in the minimum height of the channel (from 3 to $2 \mathrm{~m}$ ) resulted in an increase of the minimum, average and maximum temperatures of $0.37,1.4$ and $3.56^{\circ} \mathrm{C}$, respectively, and, consequently, the chives crop yields had a $4.78 \%$ higher fresh weight, with a confidence level of $95 \%$.
\end{abstract}

School of Economics and Business Administration, University of Almeria, Almeria (Spain).

2 Faculty of Engineering, Department of Civil and Agricultural Engineering, Universidad Nacional de Colombia, Bogota (Colombia).

3 Department of Rural Engineering, BITAL - Centre for Research in Agrifood Biotechnology, University of Almeria, Almeria (Spain).

4 Corresponding author. nebuva@hotmail.com 


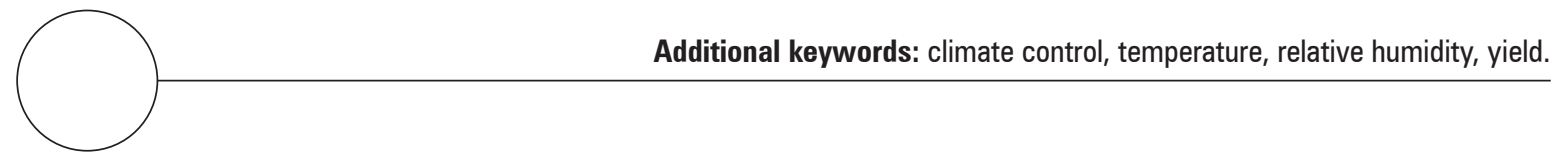

\section{RESUMEN}

El objetivo del estudio fue evaluar la incidencia de la altura del invernadero sobre la producción en un cultivo de cebollín. Los ensayos se realizaron en tres invernaderos de iguales dimensiones, variando solamente su altura de canal de 2; 2,5 m y 3 m respectivamente, ubicados en el Carmen de Viboral, Antioquia (6 $05^{\circ} 09^{\prime \prime} \mathrm{N}$ y 75²0'19"W, $2.150 \mathrm{msnm}$ ). Se realizaron mediciones de temperatura y humedad relativa cada 30 min por 3 años, durante los cuales se evaluó la producción del cultivo. Se realizaron análisis de regresión lineal múltiple, análisis de colinealidad y análisis de heterocedasticidad para determinar las variaciones climáticas causadas por la diferencia de altura entre los invernaderos y para determinar las diferencias en los niveles de producción. Se utilizó el software SPSS para el análisis estadístico. Los resultados indican que para las condiciones del estudio, la altura del invernadero afecta directamente las condiciones climáticas internas, donde una reducción de $1 \mathrm{~m}$ de altura de canal (pasando de 3 a $2 \mathrm{~m}$ ) genera un incremento de las temperaturas mínima, promedio y máxima de 0,$37 ; 1,42$ y $3,56^{\circ} \mathrm{C}$ respectivamente, así como un rendimiento superior en $4,78 \%$ en peso, con niveles de confiabilidad de $95 \%$

Palabras clave adicionales: control climático, temperatura, humedad relativa, rendimiento.

Received for publication: 16-03-2016 Accepted for publication: 14-05-2016

(

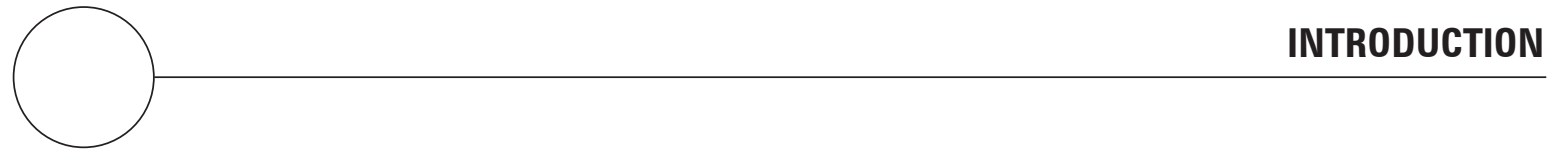

Plants that are from the same genotype, but planted under different weather conditions may have different development stages as a result of the biological life cycle, which changes with the genotype and climatic factors at the end of the same chronological time. Biological events are used as indicators for the presence or absence of certain environmental factors to draw certain conclusions or make predictions about plant responses (Brueckner and Perner, 2006; Dahlgren et al., 2007). Changes in the environment exert different pressures on plants and influence the development of each species, resulting in various forms of growth, which could be interpreted as different paths that plants have followed to adapt to a particular environment (Sherry et al., 2007).
The development rate in crops, defined as a progressive sequence of distinct morphological and physiological states, is influenced by thermal energy, the main environmental factor (Sadras et al., 2000; Lambers et al., 2008). The growth evolution, transport of assimilates, evolution of the fundamental metabolic processes, leaf expansion dynamics and biomass partition factors can be modified by environmental conditions (Salisbury and Ross, 2000). The sensitivity of the plant to ecophysiological factors depends on the species (genotype) and its developmental stage (Fischer and Melgarejo, 2014). It is very difficult to discuss the influence of the climate because of its combination with many different factors that are constantly changing during the growth 
cycle of a crop, not only with each varying factor, but also with the dynamics of all of the factors (Fischer and Orduz-Rodríguez, 2012).

Chives (Allium schoenoprasum L.) is an aromatic herb with a perennial growth habit and many self-renewal cycles in the vegetative structures with bulbils (Delahaut and Newenhouse, 2003; Abello et al., 2006; Whittinghill et al., 2013). The leaves are longer than $7 \mathrm{~cm}$ with a delicate aroma and are used in fresh consumption, improving the taste of different meals (Bernal et al., 2008; Maročkiene et al., 2013). Chives is highly adapted to the cold climates of tropical South America, at altitudes between 2,000 and 2,800 $\mathrm{m}$, and grows favorably in greenhouses (Clavijo, 2006; Barreño, 2006).

Weather is a determining factor in the growth of plants and their response to these factors depends on the variety and physiological state (Quintero and Acuña, 2014). Greenhouses are used to modify weather conditions, protect crops, and increase production and quality (González, 2009) through the appropriate selection of a film cover, changes in geometry, and ventilation area, using the combined action of wind and buoyancy forces (Roy et al., 2002; Pinzón et al., 2013).
This paper aims to show that, by changing the height of a greenhouse, different climatic conditions are generated, providing the most appropriate greenhouse height for growing chives in tropical mountains.

\section{MATERIALS AND METHODS}

Three metal multi-tunnel greenhouses, 1,523 $\mathrm{m}^{2}$, were placed in Carmen de Viboral, Antioquia (605'09" $\mathrm{N}$ and 75²0'19" W, 2,150 m a.s.l.). Each greenhouse had 33 raised beds, $1 \mathrm{~m}$ wide by $25 \mathrm{~m}$ long, with a distribution of 11 beds for a mint crop, 11 beds for chives and 11 beds for an oregano crop. All of the greenhouses had the same dimensions and roof slopes; only the channel height at the end of greenhouses was changed: $2 \mathrm{~m}, 2.5 \mathrm{~m}$ and $3 \mathrm{~m}$ (figure 1).

The structures had 1/8" galvanized longitudinal and transverse cables that were anchored to the ground, creating four $6.8 \times 56 \mathrm{~m}$ bays with $4 \mathrm{~m}$ columns. Screens are distributed around the perimeter, two side screens $(1.2 \mathrm{~m} \times 54 \mathrm{~m})$ and two front screens $(1.2 \mathrm{~m} \times 25.2 \mathrm{~m})$, operated manually, which were opened at 6 a.m. and closed at 4 p.m. (figure 2).

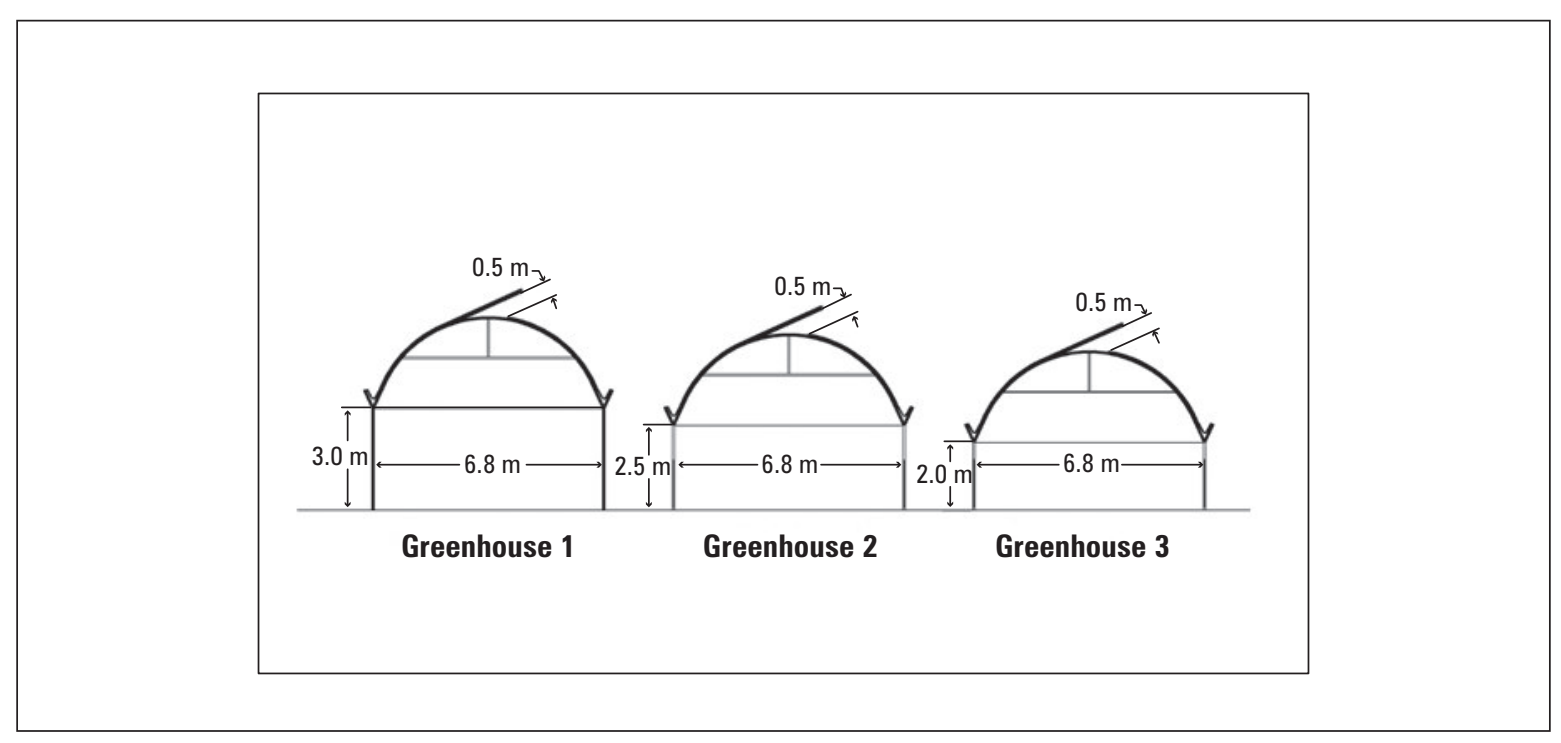

Figure 1. Dimensions of the gates of the top rear of the three greenhouses. 


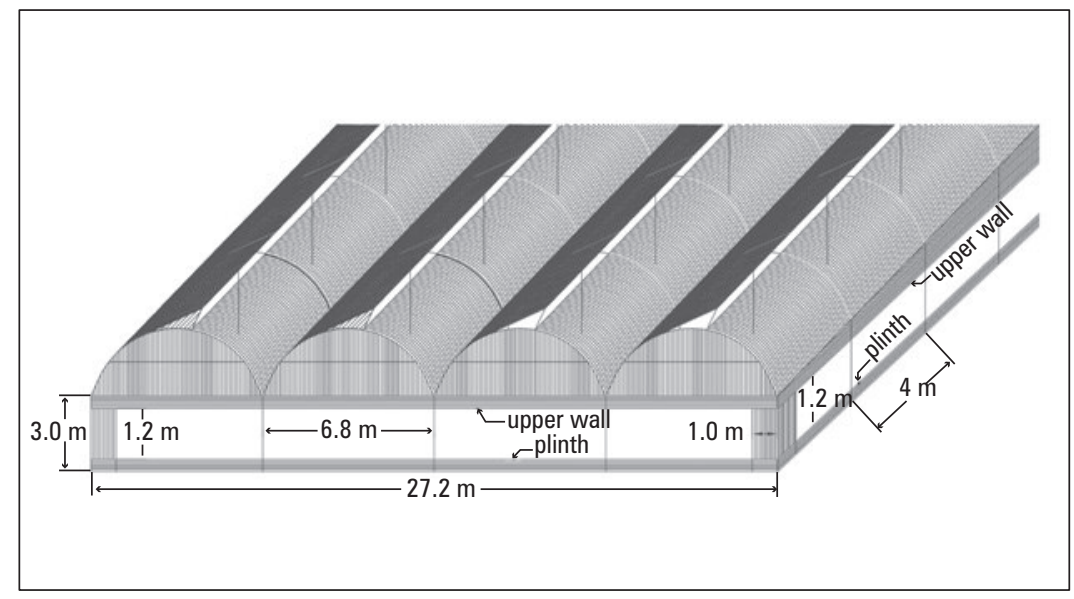

Figure 2. Section of the isometric drawing of greenhouse 3 and dimensions of the front and lateral ventilation areas.

The production was monitored in the three greenhouses and measurements of the weather conditions outside the greenhouses were taken over a period of 3 years, starting on January 5 , 2012.

A baseline irrigation, fertilization and spraying program was implemented, so that the overall handling of the three crops in these areas was a constant factor in this study. The spraying was carried out based on the monitoring taken in the field, with indications and preventive (not shock) dosages in order to not alter the product. The crop work and weeding were done every 2 weeks; hoeing was done every 3 months.

The temperature and relative humidity were analyzed in the greenhouses throughout the study, from January 5, 2012 to January 21, 2015. During this period, two full cycles of chives (12 cuts per cycle) and the first four cuts of the third cycle were measured, for a total of 308 pieces of data for the greenhouse production.

The data were subjected to a multiple linear regression to study the relationship between the two studied variables (temperature and humidity) with the response variable (production). A colinearity analysis was used to study the relationship between the two independent variables (temperature and relative humidity), which helped interpret the data obtained from the linear regression and analysis of heteroscedasticity, verifying that the variance of the input disturbance variables was not constant. For the statistical analysis, SPSS was used.

\section{ANALYSIS AND DISCUSSION OF RESULTS}

\section{Chives production data}

Table 1 shows the summarized total production of cut leaves, obtained per cycle and per greenhouse. It indicates that the highest production took place in the $2 \mathrm{~m}$-high-greenhouse, with $11,013.44 \mathrm{~kg}$ of chives produced; this greenhouse had a minimum channel height of $2 \mathrm{~m}$. While for greenhouse 1 and greenhouse 2 , the production did not differ by more than $1.15 \%$, but comparing greenhouse 1 with greenhouse 3 showed a difference in production of $5.01 \%$. 
Table 1. Total chives production per cycle and per greenhouse.

\begin{tabular}{|c|c|c|c|}
\hline Chives production (kg) & $\begin{array}{c}\text { Greenhouse 1 } \\
\text { (3.0 m height) }\end{array}$ & $\begin{array}{c}\text { Greenhouse 2 } \\
(2.5 \mathrm{~m} \text { height) }\end{array}$ & $\begin{array}{c}\text { Greenhouse 3 } \\
\text { (2.0 m height) }\end{array}$ \\
\hline Cycle 1 & $4,764.55$ & $4,97.13$ & $5,036.62$ \\
\hline Cycle 2 & $4,840.47$ & $4,809.89$ & $5,027.74$ \\
\hline Total (kg) & $9,605.02$ & $9,707.02$ & $10,064.36$ \\
\hline
\end{tabular}

The results clearly state that the best chives production took place in the low-high greenhouse. Similar results were found by Roy et al. (2002), who observed that differences between greenhouses resulted from heat lost in ventilation, providing different climate conditions for the crops. The cultivation of chives has a production cycle of 15 months; this study lasted 3 years, so the production data came from a total of 28 cuts for the cycles mentioned above.

\section{Statistical analysis}

\section{Linear regression of the chives crop data}

The regression analysis of the chives was done depending on the temperature and relative humidity as a first step for statistically evaluating the influence of these variables on the response variable, which was the production weight $(\mathrm{kg})$.

The input variables included temperature and relative humidity in the regression model, and the dependent variable was fresh weight $(\mathrm{kg})$.

Once the variables were introduced into the regression process with SPSS (Pardo and Ruiz. 2005), the results shown in table 2 were obtained (table 2).

The data showed the existence of a global linear association between the independent variables and the response variable because $R^{2}$ was different from 0 in the three greenhouses. Its magnitude suggests that the percentage explained of the variations in the response variable was given by the variations of the independent variables (Kleinbaum et al., 1988).
For instance, in the case of the $2^{\text {nd }}$ greenhouse, the model says that the joint variation of the Tmean and HRmean was explained by $10.2 \%$ the variations in the obtained fresh weight. The statistical DW for the 3 cases was lower than 2, indicating that there was a negative autocorrelation between the predicting variables. This coincides with the normal behavior of these two variables, where one has higher temperature and lower relative humidity and vice versa.

In order to determine if the regression model was valid globally, an Anova variance analysis (table 3) was performed to jointly verify the explanatory variables or predictors ( $\mathrm{RH}$ and $\mathrm{T})$, which provide information explaining the response or dependent variable (fresh weight). A similar answer was obtained in lettuce (Lactuca sativa) under two different greenhouse films by Bautista-Torres et al. (2014).

The null hypothesis in this case was that the predictor variables were not linearly related to the dependent variable. For this, the value of the F statistic was compared with the critical value given by the degrees of freedom of the table and a significance level by $5 \%$. The critical value and the comparison were calculated internally with the software, expressing the Sig value with a value equal to 0.000 . This value indicates that, with a significance level by $5 \%$, there was certainly a significant linear relationship between the crop production (measured in kilogram of fresh weight) and the relative humidity and temperature variables of each of the greenhouses. After verifying the validity of the model, we proceeded to calculate the regression 
Table 2. Linear regression model summary ${ }^{b}$.

\begin{tabular}{|l|c|c|c|c|c|}
\hline \multicolumn{1}{|c|}{ Greenhouse } & R & R square & $\begin{array}{c}\text { Adjusted } R \\
\text { square }\end{array}$ & $\begin{array}{c}\text { Std. error of the } \\
\text { estimate }\end{array}$ & Durbin-Watson \\
\hline 1 (3 m height) & $.306^{\mathrm{a}}$ & 0.094 & 0.088 & 15.548 & 0.051 \\
\hline 2 (2.5 m height) & $.320^{\mathrm{a}}$ & 0.102 & 0.096 & 15.632 & 0.068 \\
\hline 3 (2 m height) & $.311^{\mathrm{a}}$ & 0.096 & 0.091 & 15.999 & 0.076 \\
\hline
\end{tabular}

a Variables predictors: (constant), Tmean_L1, HRmean L1.

${ }^{\mathrm{b}}$ Dependent variable: fresh weight $(\mathrm{kg})$.

Table 3. Analysis of variance $^{1}$ (Anova).

\begin{tabular}{|c|c|c|c|c|c|c|}
\hline Greenhouse & & $\begin{array}{l}\text { Sum of } \\
\text { squares }\end{array}$ & df & Mean square & $\mathrm{F}$ & Sig. \\
\hline \multirow[t]{3}{*}{1} & Regression & 7632.08 & 2 & 3816.04 & 15.79 & $.000^{2}$ \\
\hline & Residual & 73729.94 & 305 & 241.74 & & \\
\hline & Total & 81362.02 & 307 & & & \\
\hline \multirow{3}{*}{2} & Regression & 8480.34 & 2 & 4240.17 & & \\
\hline & Residual & 74528.09 & 305 & 244.35 & 17.35 & $.000^{2}$ \\
\hline & Total & 83008.44 & 307 & & & \\
\hline \multirow{3}{*}{3} & Regression & 8337.51 & 2 & 4168.75 & & \\
\hline & Residual & 78070.61 & 305 & 255.97 & 16.29 & $.000^{2}$ \\
\hline & Total & 86408.11 & 307 & & & \\
\hline
\end{tabular}

${ }^{1}$ Dependent variable: fresh weight $(\mathrm{kg})$.

${ }^{2}$ Variables predictors: (constant), Tmean_L1, HRmean_L1.

coefficients, as shown in table 4.

The $t$ test values and their level of significance (Sig.) are used to compare the null hypothesis with the respective regression coefficients take a zero value. According to the results, the null hypothesis is rejected in all cases, that is, all of the obtained coefficients were relevant to the regression equation. Meanwhile, the values of statistical collinearity showed that this charac-

\section{Greenhouse 1 equation:}

Fresh weight $(\mathrm{kg})=-472.36+$ HRmean 7,889* $-9,928 *$ Tmean

\section{Greenhouse 2 equation:}

$$
\text { Fresh weight }(\mathrm{kg})=-615.77+9.49 * \text { HRmean }-9.43 * \text { Tmean }
$$


Greenhouse 3 equation:

Fresh weight $(\mathrm{kg})=-441.32+7.72 *$ HRmean $-10.84 *$ Tmean

assumptions of normality and homoscedasticity of residue, i.e. the behavior of the differences between the equation predicted values and the actual value follows the normal distribution. In order to evaluate this, the normal probability of curves shown in figure 3 is devised:

As shown in the charts, in all three cases, there was a tendency of the point cloud to align to the diagonal line on the graph, which indicates that the normality assumption in the data is true.

\section{Regression collinearity analysis of the chives crop data}

The collinearity analysis helped to confirm if there was high ratio of dependent or predictor variables. This happened because of the inverse relationship between temperature and relative humidity under normal conditions. In order to verify statistically, a collinearity test is done, which results are shown in table 5 .
The three methods of Pardo and Ruiz (2005) to interpret the above table to determine the presence of collinearity are as follows:

- When most of the eigenvalues are close to zero.

- When the condition indexes are greater than 30 .

- For higher indexes, when two or more factors have a larger proportion to the variance.

These three conditions are met for all greenhouses, meaning that it is confirmed that the data obtained from measurements stored are consistent with the normal behavior of these two variables.

\section{Correlations of the chives crop data}

For the assumption of normality in the data $(n=308)$, at the beginning, a Pearson correlation (table 6) was done, which was performed when the data followed a normal distribution. Additionally, two additional correlations were used,

Table 4. Linear regression model-coefficients ${ }^{1}$.

\begin{tabular}{|c|c|c|c|c|c|c|c|c|}
\hline \multirow{2}{*}{ Greenhouse } & \multirow{2}{*}{ Variables } & \multicolumn{2}{|c|}{$\begin{array}{c}\text { Unstandardized } \\
\text { coefficients } \\
\end{array}$} & \multirow{2}{*}{$\begin{array}{c}\begin{array}{c}\text { Standardized } \\
\text { coefficients }\end{array} \\
\text { Beta }\end{array}$} & \multirow[t]{2}{*}{$\mathrm{t}$} & \multirow{2}{*}{ Sig. } & \multicolumn{2}{|c|}{ Collinearity statistics } \\
\hline & & B & Std. error & & & & Tolerance & VIF \\
\hline \multirow{3}{*}{1} & (constant) & -472.36 & 677.487 & & -0.69 & 0.486 & & \\
\hline & HRmean & 7.889 & 6.915 & 0.131 & 1.141 & 0.255 & 0.224 & 4.455 \\
\hline & Tmean & -9.928 & 6.196 & -0.184 & -1.60 & 0.11 & 0.224 & 4.455 \\
\hline \multirow{3}{*}{2} & (constant) & -615.77 & 681.14 & & -0.90 & 0.37 & & \\
\hline & HRmean & 9.49 & 6.95 & 0.16 & 1.37 & 0.17 & 0.22 & 4.46 \\
\hline & Tmean & -9.43 & 6.23 & -0.17 & -1.51 & 0.13 & 0.22 & 4.46 \\
\hline \multirow{3}{*}{3} & (constant) & -441.32 & 697.14 & & -0.63 & 0.53 & & \\
\hline & HRmean & 7.72 & 7.12 & 0.13 & 1.09 & 0.28 & 0.22 & 4.46 \\
\hline & Tmean & -10.84 & 6.38 & -0.20 & -1.70 & 0.09 & 0.22 & 4.46 \\
\hline
\end{tabular}

${ }^{1}$ Dependent variable: fresh weight $(\mathrm{kg})$. 
Table 5. Collinearity diagnostics ${ }^{1}$.

\begin{tabular}{|c|c|c|c|c|c|c|}
\hline \multirow{2}{*}{ Greenhouse } & \multirow{2}{*}{ Dimension } & \multirow{2}{*}{ Eigenvalue } & \multirow{2}{*}{$\begin{array}{c}\text { Condition } \\
\text { index }\end{array}$} & \multicolumn{3}{|c|}{ Variance proportion } \\
\hline & & & & (constant) & HRmean_L1 & Tmean_L1 \\
\hline \multirow{3}{*}{1} & 1 & 3 & 1 & 0 & 0 & 0 \\
\hline & 2 & 0 & 106.068 & 0 & 0 & 0.19 \\
\hline & 3 & $9.69 \mathrm{E}-07$ & 1759.752 & 1 & 1 & 0.81 \\
\hline \multirow{3}{*}{2} & 1 & 3 & 1 & 0 & 0 & 0 \\
\hline & 2 & 0 & 106.068 & 0 & 0 & 0.19 \\
\hline & 3 & 9.69E-07 & 1759.752 & 1 & 1 & 0.81 \\
\hline \multirow{3}{*}{3} & 1 & 3 & 1 & 0 & 0 & 0 \\
\hline & 2 & 0 & 106.068 & 0 & 0 & 0.19 \\
\hline & 3 & $9.687 \mathrm{E}-07$ & 1759.752 & 1 & 1 & 0.81 \\
\hline
\end{tabular}

${ }^{1}$ Dependent variable: fresh weight $(\mathrm{kg})$.

the Kendall Tau_b (table 7) and the Spearman Tau_b (table 8), which are used as alternatives to Pearson, when the studied variables violate the assumption of normality.

By analyzing the signs of the three correlation coefficients, it was shown that in all cases a significant negative correlation between the relative humidity and the fresh weight of the crop occurred. Similarly, regarding the temperature, there was a significant negative correlation between the relative humidity and the fresh weight. This is consistent with the production results obtained in the three greenhouses, where greenhouse 3 , which was the warmest, had the highest production levels, and in turn, greenhouse 1, which was the coldest, had the lowest yields. It is worth noting that the strongest coefficient was the one from the reverse correlation between temperature and relative humidity, which is explained by the strong inverse relationship of these variables.

Since temperature influences more than the tissue growth of plants, it is possible that this combination of a higher temperature and a lower relative humidity in the $2 \mathrm{~m}$-high-greenhouse had the most favorable influence on the production cycle of the chives leaves (Salisbury and Ross, 2000). Chives production has a range between
15 to $25^{\circ} \mathrm{C}$ (Villamizar, 2003). An increase in the optimum crop temperature range favors quicker physiological processes because of an increase in the kinetic energy of the enzymatic systems (Fischer and Orduz-Rodríguez, 2012).

\section{Heteroscedasticity analysis}

After statistically checking the influence of the relative humidity and temperature in the production of each culture for each greenhouse, an analysis of the behavior of the variation in both climate variables between the three greenhouses was done regardless of the response variable. This led to the conclusion of a statistical presence of different microclimates among the three evaluated greenhouses.

In order to do that, an analysis of variance $(n=113)$ of two variables evaluating the behavior of their minimum, maximum and average in both cases was made, so that the analysis goes from two to six variables (table 9).

In all cases, the standard deviation was similar among the analyzed variables, so this implies that the data have a similar variation with respect to its mean value. In the three greenhouses, the temperature had a similar behavior in the 
Table 6. Pearson's correlation results ${ }^{1}$.

\begin{tabular}{|c|c|c|c|c|c|}
\hline Greenhouse & Variable & Parameter & Fresh weight $(\mathrm{kg})$ & HRmean (\%) & Tmean $\left({ }^{\circ} \mathrm{C}\right)$ \\
\hline \multirow{6}{*}{ Greenhouse 1} & \multirow{2}{*}{$\begin{array}{c}\text { Fresh weight } \\
(\mathrm{kg})\end{array}$} & \multirow{2}{*}{$\begin{array}{l}\text { Pearson correlation } \\
\text { Sig. (2-tailed) }\end{array}$} & \multirow{2}{*}{1} & $.294^{* *}$ & $-.300^{* *}$ \\
\hline & & & & 0.000 & 0.000 \\
\hline & \multirow{2}{*}{$\begin{array}{l}\text { HRmean } \\
(\%)\end{array}$} & \multirow{2}{*}{$\begin{array}{l}\text { Pearson correlation } \\
\text { Sig. (2-tailed) }\end{array}$} & $.294^{* *}$ & \multirow{2}{*}{1} & $-.881^{* *}$ \\
\hline & & & 0.000 & & 0 \\
\hline & \multirow{2}{*}{$\begin{array}{c}\text { Tmean } \\
\left({ }^{\circ} \mathrm{C}\right)\end{array}$} & \multirow{2}{*}{$\begin{array}{l}\text { Pearson correlation } \\
\text { Sig. (2-tailed) }\end{array}$} & $-.300^{* *}$ & $-.881^{* *}$ & \multirow{2}{*}{1} \\
\hline & & & 0.000 & 0.000 & \\
\hline \multirow{6}{*}{ Greenhouse 2} & \multirow{2}{*}{$\begin{array}{c}\text { Fresh weight } \\
(\mathrm{kg})\end{array}$} & \multirow{2}{*}{$\begin{array}{l}\text { Pearson correlation } \\
\text { Sig. (2-tailed) }\end{array}$} & \multirow{2}{*}{1} & $.309^{* *}$ & $-.311^{* *}$ \\
\hline & & & & 0.000 & 0.000 \\
\hline & \multirow{2}{*}{$\begin{array}{c}\text { HRmean } \\
(\%)\end{array}$} & \multirow{2}{*}{$\begin{array}{c}\text { Pearson correlation } \\
\text { Sig. (2-tailed) }\end{array}$} & $.309^{* *}$ & \multirow{2}{*}{1} & $-.881^{* *}$ \\
\hline & & & 0.000 & & 0.000 \\
\hline & \multirow{2}{*}{$\begin{array}{c}\text { Tmean } \\
\left({ }^{\circ} \mathrm{C}\right) \\
\end{array}$} & \multirow{2}{*}{$\begin{array}{c}\text { Pearson correlation } \\
\text { Sig. (2-tailed) }\end{array}$} & $-.311^{* *}$ & $-.881^{* *}$ & \multirow{2}{*}{1} \\
\hline & & & 0.000 & 0.000 & \\
\hline \multirow{6}{*}{ Greenhouse 3} & \multirow{2}{*}{$\begin{array}{c}\text { Fresh weight } \\
(\mathrm{kg})\end{array}$} & \multirow{2}{*}{$\begin{array}{c}\text { Pearson correlation } \\
\text { Sig. (2-tailed) }\end{array}$} & \multirow{2}{*}{1} & $.297^{* *}$ & $-.305^{* *}$ \\
\hline & & & & 0.000 & 0.000 \\
\hline & \multirow{2}{*}{$\begin{array}{c}\text { HRmean } \\
(\%)\end{array}$} & \multirow{2}{*}{$\begin{array}{c}\text { Pearson correlation } \\
\text { Sig. (2-tailed) }\end{array}$} & $.297^{* *}$ & \multirow{2}{*}{1} & $-.881^{* *}$ \\
\hline & & & 0.000 & & 0.000 \\
\hline & \multirow{2}{*}{$\begin{array}{c}\text { Tmean } \\
\left({ }^{\circ} \mathrm{C}\right)\end{array}$} & \multirow{2}{*}{$\begin{array}{l}\text { Pearson correlation } \\
\text { Sig. (2-tailed) }\end{array}$} & $-.305^{* *}$ & $-.881^{* *}$ & \multirow{2}{*}{1} \\
\hline & & & 0.000 & 0.000 & \\
\hline
\end{tabular}

${ }^{1} \mathrm{n}=308$.

${ }^{* *}$ Correlation is significant at the 0.01 level (2-tailed).

Table 7. Kendall's tau-b correlation results ${ }^{1}$.

\begin{tabular}{|c|c|c|c|c|c|}
\hline Greenhouse & Variable & Parameter & Fresh weight (kg) & HRmean (\%) & Tmean $\left({ }^{\circ} \mathrm{C}\right)$ \\
\hline \multirow{6}{*}{1} & \multirow{2}{*}{$\begin{array}{c}\text { Fresh weight } \\
(\mathrm{kg})\end{array}$} & \multirow{2}{*}{$\begin{array}{l}\text { Correlation coefficient } \\
\text { Sig. (2-tailed) }\end{array}$} & \multirow[t]{2}{*}{1} & $.218^{* *}$ & $-.221^{* *}$ \\
\hline & & & & 0.000 & 0.000 \\
\hline & \multirow{2}{*}{$\begin{array}{c}\text { HRmean } \\
(\%)\end{array}$} & \multirow{2}{*}{$\begin{array}{l}\text { Correlation coefficient } \\
\text { Sig. (2-tailed) }\end{array}$} & $-.218^{* *}$ & \multirow[t]{2}{*}{1} & $-.680^{* *}$ \\
\hline & & & 0.000 & & 0 \\
\hline & \multirow{2}{*}{$\begin{array}{c}\text { Tmean } \\
\left({ }^{\circ} \mathrm{C}\right)\end{array}$} & \multirow{2}{*}{$\begin{array}{l}\text { Correlation coefficient } \\
\text { Sig. (2-tailed) }\end{array}$} & $+.221^{* *}$ & $-.680 * *$ & \multirow[t]{2}{*}{1} \\
\hline & & & 0.000 & 0.000 & \\
\hline \multirow{6}{*}{2} & \multirow{2}{*}{$\begin{array}{c}\text { Fresh weight } \\
(\mathrm{kg})\end{array}$} & \multirow{2}{*}{$\begin{array}{l}\text { Correlation coefficient } \\
\text { Sig. (2-tailed) }\end{array}$} & \multirow[t]{2}{*}{1} & $.234^{* *}$ & $-.238^{* *}$ \\
\hline & & & & 0.000 & 0.000 \\
\hline & \multirow{2}{*}{$\begin{array}{c}\text { HRmean } \\
(\%)\end{array}$} & \multirow{2}{*}{$\begin{array}{c}\text { Correlation coefficient } \\
\text { Sig. (2-tailed) } \\
\end{array}$} & $-.234^{* *}$ & \multirow[t]{2}{*}{1} & $-.680 * *$ \\
\hline & & & 0.000 & & 0.000 \\
\hline & \multirow{2}{*}{$\begin{array}{c}\text { Tmean } \\
\left({ }^{\circ} \mathrm{C}\right) \\
\end{array}$} & \multirow{2}{*}{$\begin{array}{c}\text { Correlation coefficient } \\
\text { Sig. (2-tailed) }\end{array}$} & $+.238^{* *}$ & $-.680 * *$ & \multirow[t]{2}{*}{1} \\
\hline & & & 0.000 & 0.000 & \\
\hline \multirow{6}{*}{3} & \multirow{2}{*}{$\begin{array}{c}\text { Fresh weight } \\
(\mathrm{kg})\end{array}$} & \multirow{2}{*}{$\begin{array}{l}\text { Correlation coefficient } \\
\text { Sig. (2-tailed) }\end{array}$} & 1 & $.217^{* *}$ & $-.219^{* *}$ \\
\hline & & & . & 0.000 & 0.000 \\
\hline & \multirow{2}{*}{$\begin{array}{c}\text { HRmean } \\
(\%)\end{array}$} & \multirow{2}{*}{$\begin{array}{c}\text { Correlation coefficient } \\
\text { Sig. (2-tailed) } \\
\end{array}$} & $-.217^{* *}$ & \multirow[t]{2}{*}{1} & $-.680 * *$ \\
\hline & & & 0.000 & & 0.000 \\
\hline & Tmean & Correlation coefficient & $+.219^{* *}$ & $-.680^{* *}$ & 1 \\
\hline & $\left({ }^{\circ} \mathrm{C}\right)$ & Sig. (2-tailed) & 0.000 & 0.000 & \\
\hline
\end{tabular}

$1 \mathrm{n}=308$.

${ }^{* *}$ Correlation is significant at the 0.01 level (2-tailed). 
Table 8. Spearman's correlation results ${ }^{1}$.

\begin{tabular}{|c|c|c|c|c|c|}
\hline Greenhouse & Variable & Parameter & Fresh weight $(\mathrm{kg})$ & HRmean (\%) & Tmean $\left({ }^{\circ} \mathrm{C}\right)$ \\
\hline \multirow{6}{*}{1} & \multirow{2}{*}{$\begin{array}{l}\text { Fresh weight } \\
(\mathrm{kg})\end{array}$} & \multirow{2}{*}{$\begin{array}{l}\text { Correlation coefficient } \\
\text { Sig. (2-tailed) }\end{array}$} & \multirow[t]{2}{*}{1} & $.338^{* *}$ & $-.308^{* *}$ \\
\hline & & & & 0.000 & 0.000 \\
\hline & \multirow{2}{*}{$\begin{array}{l}\text { HRmean } \\
(\%)\end{array}$} & \multirow{2}{*}{$\begin{array}{l}\text { Correlation coefficient } \\
\text { Sig. (2-tailed) }\end{array}$} & $-.338^{* *}$ & \multirow[t]{2}{*}{1} & $-.861^{* *}$ \\
\hline & & & 0.000 & & 0 \\
\hline & \multirow{2}{*}{$\begin{array}{c}\text { Tmean } \\
\left({ }^{\circ} \mathrm{C}\right)\end{array}$} & \multirow{2}{*}{$\begin{array}{l}\text { Correlation coefficient } \\
\text { Sig. (2-tailed) }\end{array}$} & $+.308^{* *}$ & $-.861^{* *}$ & \multirow{2}{*}{1} \\
\hline & & & 0.000 & 0.000 & \\
\hline \multirow{6}{*}{2} & \multirow{2}{*}{$\begin{array}{l}\text { Fresh weight } \\
(\mathrm{kg})\end{array}$} & \multirow{2}{*}{$\begin{array}{l}\text { Correlation coefficient } \\
\text { Sig. (2-tailed) }\end{array}$} & \multirow[t]{2}{*}{1} & $.367^{* *}$ & $-.327^{* *}$ \\
\hline & & & & 0.000 & 0.000 \\
\hline & \multirow{2}{*}{$\begin{array}{c}\text { HRmean } \\
\text { (\%) }\end{array}$} & \multirow{2}{*}{$\begin{array}{l}\text { Correlation coefficient } \\
\text { Sig. (2-tailed) }\end{array}$} & $-.367^{* *}$ & \multirow{2}{*}{$\begin{array}{l} \\
.\end{array}$} & $-.861^{* *}$ \\
\hline & & & 0.000 & & 0.000 \\
\hline & \multirow{2}{*}{$\begin{array}{c}\text { Tmean } \\
\left({ }^{\circ} \mathrm{C}\right)\end{array}$} & \multirow{2}{*}{$\begin{array}{l}\text { Correlation coefficient } \\
\text { Sig. (2-tailed) }\end{array}$} & $+.327^{* *}$ & $-.861^{* *}$ & 1 \\
\hline & & & 0.000 & 0.000 & . \\
\hline \multirow{6}{*}{3} & \multirow{2}{*}{$\begin{array}{c}\text { Fresh weight } \\
(\mathrm{kg})\end{array}$} & \multirow{2}{*}{$\begin{array}{l}\text { Correlation coefficient } \\
\text { Sig. (2-tailed) }\end{array}$} & \multirow[t]{2}{*}{1} & $.323^{* *}$ & $-.306^{* *}$ \\
\hline & & & & 0.000 & 0.000 \\
\hline & \multirow{2}{*}{$\begin{array}{c}\text { HRmean } \\
(\%)\end{array}$} & \multirow{2}{*}{$\begin{array}{l}\text { Correlation coefficient } \\
\text { Sig. (2-tailed) }\end{array}$} & $-.323^{* *}$ & \multirow{2}{*}{$\begin{array}{l}1 \\
.\end{array}$} & $-.861^{* *}$ \\
\hline & & & 0.000 & & 0.000 \\
\hline & \multirow{2}{*}{$\begin{array}{c}\text { Tmean } \\
\left({ }^{\circ} \mathrm{C}\right)\end{array}$} & \multirow{2}{*}{$\begin{array}{l}\text { Correlation coefficient } \\
\text { Sig. (2-tailed) }\end{array}$} & $+.306^{* *}$ & $-.861^{* *}$ & 1 \\
\hline & & & 0.000 & 0.000 & . \\
\hline
\end{tabular}

${ }^{1} \mathrm{n}=308$

** Correlation is significant at the 0.01 level (2-tailed).

order of values. In all three cases, the coldest greenhouse was greenhouse 1 and the warmest was greenhouse 3. Comparing the mean of the minimum temperatures, the difference between these two greenhouses was $0.37^{\circ} \mathrm{C}$; while the difference between greenhouse 2 was $0.29^{\circ} \mathrm{C}$. For the mean of the average temperatures, the difference between greenhouse 1 and greenhouse 3 was 1.42 and $1.13^{\circ} \mathrm{C}$ between greenhouse 2 and greenhouse 3 . Finally, the difference between the mean maximum temperatures was $3.56^{\circ} \mathrm{C}$ for greenhouse 1 and greenhouse 3 ; and $3.21^{\circ} \mathrm{C}$ between greenhouse 2 and greenhouse 3 .

As for the relative humidity variables, in the minimum and average variables, there was an opposite behavior, which was expected because of the negative correlation that occurred between these two variables. The greenhouse with the lowest average and minimum relative humidity was greenhouse 3, and the one with the highest values was greenhouse 1 , with differences of $6.9 \%$ in the mean of the minimum variable and $2.96 \%$ in the mean of the averages. The differences between greenhouse 3 and greenhouse 2 were $5.23 \%$ and $2.10 \%$, respectively. With respect to the maximum variables, no significant differences were found because there is a clear tendency for values very close to 100\% almost every day in the morning, both outside and inside the greenhouses.

To confirm that the differences between the descriptions were meaningful, an ANOVA variance analysis was done (table 10), starting from the null hypothesis that the mean of each of the variables was the same for the three greenhouses. 
The comparison of statistic $\mathrm{F}$ resulted in the null hypothesis being rejected in all cases (Sig. $=0.000$ ), except for the HR_mean. This means that, for a confidence level of $95 \%$, it can be said that there were significant differences in the other five variables (T_MIN, T_med, t_max, Hr_min and HR_max).

\section{CONCLUSIONS}

- For a confidence level of $95 \%$, it was concluded that, by reducing the minimum height channel from $3 \mathrm{~m}$ to $2 \mathrm{~m}$, there is a difference in the microclimate of the greenhouse in the study, which produced an increase of $4.78 \%$ in the production of the chives, which resulted in a rise of income.

- The microclimate generated in each greenhouse was described by the differences in the five variables with which the heteroscedasticity analysis (Tmean, Tmin, Tmax, minimum $\mathrm{HR}$ and HR mean) was done. It was conclu- ded that, for a confidence level of $95 \%$, the reduction of $1 \mathrm{~m}$ in the minimum height of the channel resulted in an increase of: of $0.37^{\circ} \mathrm{C}$ in the minimum temperature, $1.42^{\circ} \mathrm{C}$ in the average temperature and $3.56^{\circ} \mathrm{C}$ in the maximum temperature.

- In the case of relative humidity, the $1 \mathrm{~m}$ reduction of the minimum height resulted in a decrease in the minimum relative humidity of $6.9 \%$ and $2.96 \%$ in the average relative humidity. The inverse relationship between the relative humidity and temperature was due to the high negative statistical correlation seen between these two variables according to the three statistical correlation methods and the Durbin Watson statistic.

- With a confidence level of $95 \%$, it was shown that there was a significant linear relationship between the joint interaction of relative humidity and temperature and the production of chives crops in each of the greenhouses.

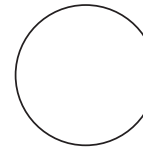

Abello, J., J. Clavijo, and P. Barreno. 2006 Estudio preliminar de algunos descriptores fisiológicos en cinco hierbas aromáticas. pp. 13-15. In: Memorias Curso de Extensión: Últimas tendencias en hierbas aromáticas culinarias para exportación en fresco. Facultad de Agronomía, Universidad Nacional de Colombia, Bogotá.

Barreño, P. 2006. Hierbas aromáticas culinarias para exportacion en fresco. Manejo agronómico, producción y costos. Facultad de Agronomía, Universidad Nacional de Colombia, Bogotá.

Bautista-Torres, A.M., J.F. Acuña, and J.L. Martin. 2014. Comportamiento de la humedad relativa en un cultivo de lechuga (Lactuca sativa) variedad Vera, bajo dos condiciones de ambiente controlado. In: Memorias XI Congreso Latinoamericano y del Caribe de Ingeniería Agrícola. Cancún, México.

Bernal, D.A., L.C. Morales, G. Fischer, J. Cuervo, and S. Magnitskiy. 2008. Caracterización de las de- ficiencias de macronutrientes en plantas de cebollín (Allium schoenoprasum L.). Rev. Colomb. Cienc. Hortic. 2(2), 192-204. Doi: 10.17584/ rcch.2008v2i2.1187

Brueckner, B. and H. Perner. 2006. Distribution of nutritive compounds and sensory quality in the leafs of chives (Allium schoenoprasum L.). J. Appl. Bot. Food Qual. 80(2), 155-159.

Clavijo, J.P. 2006. Últimas tendencias en hierbas aromáticas culinarias para exportacion en fresco. Produmedios, Bogotá.

Dahlgren, J.P., H. von Zeipel, and J. Ehrlen. 2007. Variation in vegetative and flowering phenology in a forest herb caused by environmental heterogeneity. Amer. J. Bot. 94, 1570-1576. Doi: 10.3732/ ajb.94.9.1570

Delahaut, K.A. and A.C. Newenhouse. 2003. Growing onions, garlic, leeks, and other Allium in Wiscon- 
sin: A guide for fresh-market growers. Cooperative extension. University of Wisconsin, Madison, WI.

Fischer, G. and L.M. Melgarejo. 2014. Ecofisiología de la uchuva (Physalis peruviana L.). pp. 31-47. In: Carvalho, C.P. and D.A. Moreno (eds.). Physalis peruviana: fruta andina para el mundo. Programa Iberoamericano de Ciencia y Tecnología para el Desarrollo CYTED, Limencop SL, Alicante, Spain.

Fischer, G. and J.O. Orduz-Rodríguez. 2012. Ecofisiología en frutales. pp. 54-72. In: Fischer, G. (ed.). Manual para el cultivo de frutales en el trópico. Produmedios, Bogotá.

González, M.M. 2009. La gestión del clima bajo invernadero y modelos de simulación para su manejo. Memorias Curso Control climático en invernaderos. Universidad de Almería, Almería, España.

Kleinbaum,D.G.,L.L.Kupper, andK.Muller.1988.Applied regression analysis and other multivariate methods. PWS-KENT Publishing Company, Kent, UK.

Lambers, H., T.L. Pons, and S. Chapin. 2008. Plant physiological ecology. 2nd ed. Springer Verlag, New York, NY.

Maročkiene, N., R. Karkleliene, D. Juškevičiene, and A. Radzevičius. 2012. Investigation of morphobiological parameters of local and introduced cultivars of chives (Allium schoenoprasum L.). J. Sodininkyste Daržininkyste 31(3/4), 59-65.

Pardo, M. and D. Ruiz. 2005. Análisis de datos con SPSS 12 Base. McGraw-Hill, Madrid.

Pinzón, A.M., B. Castillo, and M.T. Londoño. 2013. Characterization of the mechanical properties of chives (Allium schoenoprasum L.). Agron. Colomb. 31(1), 83-88.

Quintero, G. and J.F. Acuña. 2014. Incidencia de las películas plásticas en la variación de factores abióticos para producción de lechuga en ambientes protegidos. In: Memorias VI Edición de la conferencia científica internacional sobre desarrollo agropecuario y sostenibilidad. Agrocentro, Universidad Central "Martha Abreu" de Las Villas, Cuba.

Roy, J.C., T. Boulard, C. Kittas, and S. Wang. 2002. Convective and ventilation transfers in greenhouses, Part 1: the greenhouse considered as a perfectly stirred tank. Biosyst. Eng. 83, 12-14. Doi:10.1006/ bioe. 2002.0107

Sadras, V.O., L. Echarte, and F.H. Andrade. 2000. Profiles of leaf senescence during reproductive growth of sunflower and maize. Ann. Bot. 85, 187-195. Doi: 10.1006/anbo.1999.101.

Salisbury, F.B. and C.W. Ross. 2000. Fisiología de las plantas. Vol. 3. Desarrollo de las plantas y fisiología ambiental. Paraninfo and Thomson Learning, Madrid.

Sherry, R.A., X.H. Zhou, and S.L. Gu. 2007. Divergence of reproductive phenology under climate warming. Proc. Nat. Acad. Sci. USA. 104, 198-202. Doi 10.1073/pnas.0605642104.

Villamizar, F. 2003. Calidad poscosecha y uso del frío en la conservación de hierbas frescas para la exportación. pp. 51-55. In: Memorias curso de extensión teórico práctico "Últimas tendencias en hierbas aromáticas culinarias para exportación en fresco". Facultad de Agronomía, Universidad Nacional de Colombia, Bogotá.

Whittinghill, L.J., D.B. Rowe, M. Ngouajio, and B.M. Cregg. 2013. Evaluation of nutrient management and mulching strategies for vegetable production on an extensive green roof. Agroecol. Sustainable Food Syst. 40(4), 297-318. Doi: 10.1080/21683565.2015.1129011 